\title{
DAMPAK PROGRAM PELATIHAN TEKNIS FUNGSIONAL GURU TERHADAP SIKAP SOSIAL GURU MADRASAH
}

\author{
Yasri \\ Pusdiklat Tenaga Teknis Pendidikan dan Keagamaan \\ Badan Litbang dan Diklat Kementerian Agama RI \\ e-mail:yasri3469@yahoo.com
}

\begin{abstract}
ABSTRAK
Artikel ini bertujuan untuk mengungkapkan hasil penelitian evaluasi dampak program pelatihan teknis fungsional guru madrasah aspek sosial yang diselenggarakan oleh Pusat pelatihan tenaga teknis pendidikan dan keagamaan Kementerian Agama. Penelitian ini menggunakan metode study kasus dan survei yang dilakukan di 20 Madrasah DKI Jakarta dengan 160 responden yang terdiri dari alumni peserta pelatihan, teman sejawat, dan atasan alumni. Teknik pengambilan data dilakukan dengan wawancara, observasi, dan angket. Teknik pengolahan data dilakukan secara kuantitatif dan kualitatif deskriptif. Hasil penelitian ini menunjukan bahwa alumni pelatihan mampu menerapkan hasil pembelajaran yang didapat dan perubahan yang ditimbulkan, menjaga kesinambungan dari perubahan yang terjadi, meningkatkan kepedulian terhadap tingkat perubahan, bersosialisasi dengan teman dan atasan secara baik, melakukan kerjasama secara bersamaan, menerima dan memberi saran, meningkatnya kedisiplinan, dan memiliki loyalitas dan persepsi terhadap pekerjaan. Namun secara rata-rata alumni belum terampil dalam mengimplementasikan pengetahuan dan keterampilan yang relevan untuk digunakan dalam bekerja. Kemampuan tersebut tidak sepenuhnya akibat dari peran Pusdiklat Teknis Kementerian Agama.
\end{abstract}

Kata Kunci : Dampak, pelatihan, Sikap Sosial Alumni

\section{ABSTRACT}

This article aims to reveal the results of the impact evaluation evaluation of the functional technical training program of madrasah teacher social aspect organized by the Ministry of Religion's technical and religious education technical center. This study uses case study and survei method conducted in 20 Madrasah DKI Jakarta with 160 respondents consisting of alumni of 
trainees, colleagues, and alumni's supervisor.Technique of data retrieval is done by interview, observation, and questionnaire. Data processing technique is done in quantitative and qualitative descriptive. The results of this study indicate that the training alumni are able to apply the learning outcomes and the changes they generate, maintain the continuity of the changes, increase awareness of the level of change, socialize with friends and superiors well, cooperate simultaneously, receive and advise, discipline, and have loyalty and perception of work. However, on average, alumni are not yet skilled in implementing relevant knowledge and skills for use in work. This capability is not entirely due to the role of the Ministry of Religious Affairs' Technical Counseling Center.

Keywords: Impact, Training, Alumni Social Attitude

\section{PENDAHULUAN}

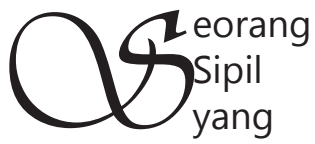

Aparatur
Negara (ASN)
melaksanakan tugas dan fungsi sebagai tenaga pendidik harus mempunyai empat kompetensi. Salah satu diantaranya adalah kompetensi sosial (Permendiknas Nomor 16 tahun 2007). Kompetensi sosial setiap ASN setiap saat harus dipertajam dan dapat ditingkatkan melalui berbagai kegiatan, antara lain melalui pengembangan diri dan program pendidikan dan pelatihan (Diklat).

Diklat merupakan program yang bertujuan meningkatkan dan mengembangkan kompetensi pegawai baik pengetahuan, keterampilan maupun sikap sosial agar dalam pelaksanaan tugas dan jabatan dapat dilakukan secara profesional, berkepribadian dan beretika (UU RI Nomor 5 Tahun 2014, pasal 70 dan PP RI Nomor 101 Tahun 2000: pasal 2 ayat a).
Salah satu lembaga diklat yang melaksanakan Diklat pegawai adalah Pusat pendidikan dan Pelatihan (Pusdiklat) Tenaga Teknis Pendidikan dan Keagamaan.

Pusdiklat Tenaga Teknis Pendidikan dan Keagamaan sejak tahun 2001 dan berdasarkan laporan tahunan Pusdiklat Tenaga Teknis telah mendiklat guru madrasah lebih dari 7.500 orang dengan menggunakan anggaran lebih dari Rp. 60 milyar dan melaksanakan Analisis Kebutuhan Diklat (AKD), rapat koordinasi, dan rapat evaluasi program diklat tahun berjalan. Namun substansi yang dievaluasi masih terbatas pada berbagai macam kebijakan, kegiatan, dan penyerapan anggaran. Sehingga belum mengevaluasi dampak-dampak yang ditimbulkan akibat kegiatan diklat di tingkat pengguna, khususnya guru madrasah.

Pusdiklat Teknis Kementerian Agama seharusnya sudah memulai 
mengadakan evaluasi menyeluruh terhadap program diklat dan dampaknya yang berskala besar, sebagai bentuk fungsi akuntabilitas dan rencana peningkatan pemberian layanan prima kepada pengguna. Sehingga terhindar dari persepsi dan tendensi dari pemangku kepentingan yang mengatakan bahwa diklat guru kurang berdampak terhadap Sikap social bagi guru madrasah.

Rumusan masalah dalam penelitian ini adalah dampak program diklat guru madrasah dalam: (1) Bagaiman Implementasi hasil Diklat terhadap sikap guru madrasah?, (2) Bagaimana dampak program Diklat terhadap sosial kerjasama guru madrasah?

Bagaimana dampak program Diklat terhadap peningkatan sikap loyalitas guru madrasah? Sedangkan tujuan penelitian ini adalah untuk menganalisis sikap sosial alumni peserta diklat dalam mengimplementasikan hasil diklat, kerjasama, dan loyalitas terhadap civitas akademika madrasah

Kajianinididasariolehbeberapa teori, yaitu teori evaluasi program, dan evaluasi dampak program dan sikap. Evaluasi merupakan proses penyediaan informasi yang diran-cang dalam menentukan tujuan yang hendak dicapai dan membantu pengambilan keputusan berupa perencanaan, program, kebijakan, organisasi, produk, maupun individual yang dapat dibuktikan dan dinilai secara ilmiah (Stufflebeam, 2003: 34 dan Owen, 1993: 3).

Evaluasi adalah proses yang sistematik yang dimulai dari mengumpulkan, menganalisa dan menginterprestasi informasi untuk menentukan sampai dimana pencapaian peserta didik terhadap obyek-obyek yang dipelajari (Gronlund dan Linn, 1990: 5) dan untuk mengetahui kelemahan atau kekurangan yang kemudian akan diadakan perbaikan berdasarkan informasi yang diperoleh (Bonnie Campbell Hill dan Cyinthia Ruptic, 1994: 12)

Program adalah seperangkat kegiatan spesifik yang dirancang untuk tujuan yang telah ditetapkan, dan sasaran yang dapat diukur (Spauldin, 2008: 5) dan digunakan untuk menentukan bahwa sebuah program tidak efektif atau memiliki dampak mampu memperbaiki hasil (Sue Mallonee, 2000: Vol 10 No. 1). Efektif dan tidaknya sebuah program harus dilakukan melalui proses evaluasi yang menyeluruh.

Evaluasi program merupakan proses implementasi metode penelitian ilmiah untuk membuat akses dalam merencanakan, melaksanakan, menghasilkan suatu program dan mengintervensi sosial untuk keperluan pengambilan keputusan yang sistematis dan berkesinam-bungan yang melibatkan orang secara perorangan atau ber-kelompok (Roberts dan Greene, 2009: 473 dan Suharsimi A dan Cepi, 2014: 4) 
Pakar lain berpendapat bahwa evaluasi program merupakan pengukuran, pengumpulan, dan pengolahan data tentang kegiatan dan dampak dari suatu program untuk membuat kebijakan dalam meningkatkan efektivitas program (Stufflebeam dan Shinkfield, 2007: 434) dan sebagai proses kontributif pengembangan

program pendidikan dan pengambilan keputusan (Ismail Yuksel, 2012).

Berdasarkan beberapa pendapat tersebut, evaluasi program adalah proses pengukuran, pengumpulan, dan pengolahan informasi (data) secara terstruktur dan ilmiah tentang perencanaan, pelaksanaan dan hasil serta dampak dari suatu program dan dapat dijadikan rujukan untuk membuat sebuah kebijakan tertentu terhadap kelangsungan sebuh program.

Evaluasi dampak program diperlukan untuk pembuat kebijakan dan pengambilan keputusan terkait hal yang tidak efektif dari program, membuat intervensi, menilai kelebihan dan menentukan berbagai program alternative (Gertler, Paul. J, et. al, 2010: 7).

Evaluasi dampak berusaha untuk menentukan hubungan antara program dan perbaikan selanjutnya dalam kesejahteraan populasi sasaran (Khandker, et. al: The International Bank for Reconstruction and Development,
2010). Evaluasi dampak program bertujuan untuk mengetahui seberapa jauh suatu program dapat memberikan pengaruh tertentu kepada sasaran dan dampak tersebut diukur berdasar kriteria keberhasilan sebagai indikator tercapinya tujuan program (Oemar Hamalik, 1990: 67).

Abdus Sattar $\mathrm{N}$ mensinyalir bahwa suatu pelatihan yang komprehensif dapat membantu dalam mencapai tujuan lembaga untuk menciptakan keunggulan yang kompetitif melalui peningkatan kompetensi pengetahuan, keterampilan, dan sikap (Abdus Sattar Niazi, 2011: Journal of Public Administration and Governance, Vol 1 No. 2). Pakar lain menungungkapkan bahwa dampak pelatihan menjadikan kualitas kerja yang lebih baik, produktivitas, kepuasan kerja lebih, dan lebih sedikit kesalahan (Kirkpatrick, 2005: 69)

Sedangkan menurut Afshan dampak yang ditimbulkan dari proses pelatihan, antara lain dampak terhadap kinerja, gaji, dan keterlibatan pegawai. (Afshan, 2012: Institute of Interdisciplinary Business Research, vol 4, No 6)

Dengan demikian, dampak program pelatihan tidak saja dapat meningkatkan kualitas kerja, produktivitas, tingkat kepuasan kerja, dan lebih sedikit kesalahan, namun juga mampu mengikutsertakan pegawai dalam 
keterlibatannya meningkatkan lembaga atau unit kerja.

Beberapa pendapat tersebut, disimpulkan bahwa evaluasi dampak program merupakan suatu proses dalam menentukan perubahan kegiatan yang akan dilaksanakan oleh instansi atau alumni diklat berupa peningkatan kinerja yang didukung antara lain oleh peningkatan sikap sehingga memperoleh kualitas kerja yang baik.

Pelatihan merupakan upaya
yang direncanakan untuk
mempermudah pembelajaran
para guru tentang pengetahuan,
keterampilan dan sikap yang
berkaitan dengan pekerjaan
(Raymond et. Al, 2010: 351). Pelatihan mengacu pada upaya yang direncanakan oleh suatu lembaga untuk mempermudah pembelajaran guru tentang kompetensi yang berkaitan dengan pengetahuan, keterampilan, atau sikap (PP RI Nomor 101, 2000: pasal 1 dan 2 dan Primajaya, 2012: 6)

Konsep di atas didukung oleh regulasi lain yang menyatakan bahwa diklat merupakan kegiatan proses pembelajaran dalam upaya peningkatan kompetensi pegawai Kementerian Agama dengan durasi waktu minimal 40 jam pelajaran, dengan lama waktu 45 menit per jam pelajaran. (PMA Nomor 4 tahun 2012).

Pendapat di atas dapat disimpulkan bahwa pelatihan adalah kegiatan proses pembelajaran yang direncanakan untuk membantu peserta pelatihan dalam memahami dan pengembangan pengetahuan, keterampilan dan sikap yang berkaitan dengan impact.

Muatan kurikulum Diklat Teknis Fungsional Peningkatan Kompetensi bagi guru antara lain mengkaji tentang mensinergikan kecerdasan Intelectual Quotient (IQ), Emotional Qoutient (EQ) dan Spiritual Qoutient (SQ), memahami kesadaran membangun budaya kerja pegawai, pengembangan sumber daya manusia dan karakter; membangun disiplin, pribadi teladan dan budaya organisasi.

Sikap merupakan suatu kecenderungan untuk memberikan tanggapan menyenangkan atau tidak menyenangkan terhadap suatu objek tertentu, kecenderungan ini merupakan hasil belajar atau karena pengaruh sosial kehidupan sehari-hari, bukan karena pembawaan ataupun keturunan. Menurut pendapat Krech, Crutchfield dan Ballachey yang dikutip Werner J. Severin \& James W. Tankard, JR (2009: 179) mengatakan bahwa sikap adalah sebuah sistem evaluasi positif atau negatif yang awet, perasaan-perasaan emosional dan tendensi tindakan pro atau kontra terhadap sebuah objek sosial. Sikap juga dapat dimaknai Suatu kecenderungan untuk bereaksi dengan cara tertentu terhadap 
sesuatu perangsang atau situasi yang dihadapi (Ngalim Purwanto, 2006:141).

Sikap sosial alumni peserta diklat dimaksud adalah sikap dalam mengimplementasikan hasil diklat, sikap kerjasama dan sikap perilaku dan loyalitas di unit kerja alumni peserta diklat bekerja (madrasah). Komponen implementasi hasil diklat terdiri dari: penerapan hasil pembelajaran dan perubahan yang ditimbulkan, pengetahuan dan keterampilan yang relevan yang digunakan dalam bekerja, kesinambungan dari perubahan yang terjadi, dan kepedulian terhadap tingkat perubahan. Komponen kerjasama terdiri dari: bersosialisasi dengan teman dan atasan, bekerja secara bersamaan (team work), menerima dan memberi saran. Sedangkan komponen perilaku dan loyalitas terdiri dari: kedisiplinan dan loyalitas terhadap pekerjaan.

Upaya evaluasi perlu adanya penetapan standar pelaksanaan yang sudah ditetapkan (Robert E. Stake, 2004: dan Djaali dan Mulyono, 2008: 1). Kriteria dampak yang digunakan diklasifikasi menjadi 5 kategori, yaitu: sangat baik $(92,00-100,00)$, baik $(84,00$ - 91,99), cukup (76,00 - 83,99), kurang $(68,00-75,99)$, dan sangat kurang $(<68,00)$ (Panduan Evaluasi Diklat Teknis di Lingkungan Kementerian Agama, 2013: 5).

\section{METODE PENELITIAN}

Penelitian ini dilaksanakan di 20 Madrasah Tsanawiyah Negeri (MTsN) di Wilayah binaan Kantor Wilayah Kementerian Agama DKI Jakarta dengan subyek penelitian berjumlah 160 orang yang terdiri dari alumni peserta diklat $(60$ Orang), atasan alumni (40 orang) dan teman sejawat alumni (60 orang).

Waktu penelitian ini dilakukan selama 6 bulan dimulai dari bulan Januari sampai dengan Juni 2017. Metode penelitian ini menggunakan metode studi kasus (case study) dan survei. Metode ini sering digunakan pada penelitian sosial dengan tujuan untuk mengungkap fenomena sosial yang terjadi secara lebih mendalam dan diperlukan pada saat timbul pertanyaan bagaimana dan mengapa pada suatu fenomena sosial yang akan diteliti (Robert K. Yin, 2003: 1).

Model yang digunakan dalam penelitian evaluasi dampak program diklat ini adalah model yang dikembangkan oleh Yasri (2017:70). Model ini digunakan karena mampu mengungkapkan hasil diklat sampai ke tahap outcome, yaitu bagaimana dampak sebuah program diklat terhadap prilaku alumni peserta diklat dengan melihat berbagai komponen, antara lain komponen kompetensi alumni, kinerja alumni, kinerja unit Kerja, dan sikap sosial alumni peserta diklat. 
Lebih jelasnya model yang digunakan dalam penelitian ini dapat dilihat pada gambar 1 seperti berikut:

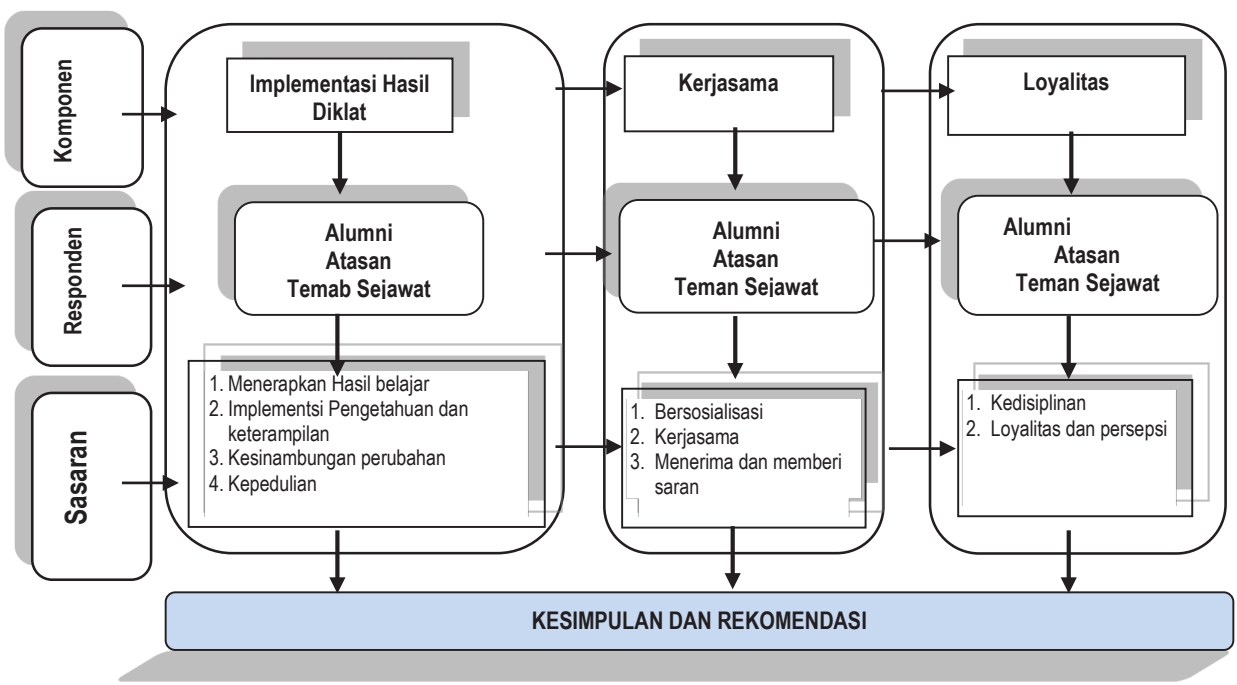

Gambar 1. Desain Penelitian Evaluasi Sikap Sosial Guru Madrasah

Model di atas, terlihat bahwa dalam penelitian ini terdapat tiga hal penting yang perlu dirancang, yaitu komponen yang akan diteliti, responden yang akan dijadikan sumber data dan sasaran yang akan diukur. Penelitian ini mengungkap dampak diklat dalam tiga komponen, yaitu: bagaimana alumni peserta diklat dalam mengimplementasikan hasil diklat, bagaimana proses kerjasama yang terjalin antar sesama guru dan atasan, serta bagaimana tingkat loyalitas alumni peserta diklat terhadap tugas dan pimpinan. Sedangkan responden yang dilibatkan adalah alumni peserta diklat, unsur pimpinan atau atasan alumni, dan teman sejawat alumni.

Model penelitian ini juga menggambarkan penelitian berdasarkan tiap komponen penelitian, yaitu: sasaran komponen implementasi hasil diklat mengungkapkan bagaimana alumni menerapkan hasil belajar, bagaimana proses implementasi pengetahuan dan keterampilan, bagaimana membangun kesinambungan sebuah perubahan, dan sejauh mana kepedulian alumni terhadap sistem kerja di madrasah. Sedangkan sasaran dalam komponen kerjasama adalah bagaimana membangun sosialisasi, kerjasama dan menerimaa serta memberi saran. Penelitian ini juga mengukur tingkat kedisiplinan dan tingkat loyalitas serta persepsi dalam komponen loyalitas.

Teknik pengumpulan data dalam penelitian ini disesuaikan 
dengan komponen data yang akan dicari, yaitu menggunakan angket dengan skala likert, pedoman wawancara, dan lembar observasi. Untuk mendukung data hasil angket dilakukan triangulasi, yaitu melakukan dialog langsung kepada subjek yang berkaitan dengan informasi yang dibutuhkan. Dalam hal ini dilakukan wawancara kepada alumni diklat, atasan dan teman sejawat alumni peserta diklat.

Data hasil penelitian evaluasi dampak program diklat aspek sikap sosial alumni peserta diklat ini dianalisis berdasarkan jenis dan teknik analisis data yang sesuai dalam rangka menjawab pertanyaan penelitian. Data hasil penelitian dianalisis secara deskriptif kuantitatif dan naratif kualitatif.

Data-data berupa hasil angket dan observasi dianalisis dengan teknik kuantitatif menggunakan tendensi sentral berupa ratarata dan prosentase yang dimulai dari menskor setiap kriteria, menentukan prosentase kriteria, menemukan nilai butir tiap pernyataan, menemukan nilai tiap indikator dan disajikan dengan menggunkaan diagram garis.

Data penelitian hasil wawancara tertutup dianalisis dengan teknik kuantitatif menggunakan tendensi sentral berupa ratarata dan prosentase yang dimulai dengan menentukan skor butir, menentukan skor kategori pilihan jawaban, menentukan prosentase tiap kategori pilihan jawaban dan disajikan dalam diagram lingkaran. Hasil analisis data penelitian kuantitatif tersebut dilanjutkan dengan analisis deskriptif kualitatif sebagai dasar dalam pengambilan sebuah kesimpulan.

Sedangkan data hasil wawancara terbuka digunakan untuk menjawab pertanyaan evaluasi pada masing-masing komponen yang dianalisis secara naratif kualitatif.

Analisis data wawancara terbuka dilakukan dengan empat tahapan. Tahap pertama merekap dan mengklasifikasi hasil wawancara dari responden menjadi tiga kalsifikasi pernyataan sesuai dengan butir pertanyaan yang diajukan. Tahap kedua menganalisis dan mensintesis masing-masing klasifikasi penyataan, dan tahapan ketiga menyimpulkan hasil sinteses untuk dijadikan pertimbangan dalam merumuskan rekomendasi.

Secara keseluruhan dampak program diklat aspek Sikap sosial yang sudah dianalisis dibandingkan dengan standar/ kriteria yang digunakan dalam pengelolaan program kediklatan yang telah ditetapkan.

Teknik analisis data diawali dengan menganalisis skor setiap pernyataan, pengamatan dan pertanyaan dengan menggunakan prosentase, sehingga menghasilkan suatu nilai yang nantinya 
dijadikan bahan pertimbangan dalam menyimpulkan hasil penelitian

\section{TEMUAN DAN PEMBAHASAN}

\section{Temuan}

Temuan pada penelitian evaluasi sikap sosial bagi alumni peserta diklat guru madrasah difokuskan pada dua hal, yaitu dampak diklat terhadap kompetensi sikap sosial alumni peserta diklat dan peran Pusdiklat dalam meningkatkan kompetensi sikap sosial. Kompetensi yang ditemukan dalam penelitian ini terdiri tiga aspek, yaitu Implementasi hasil diklat dengan empat butir pertanyaan, sikap sosial kerjasama dengan tiga pertnyaan, dan sikap loyalitas dengan dua pertanyaan.

Secara lengkap data temuan hasil penelitian hasi evaluasi sikap sosial alumni peserta diklat dapat dilihat pada gambar 2 berikut ini.

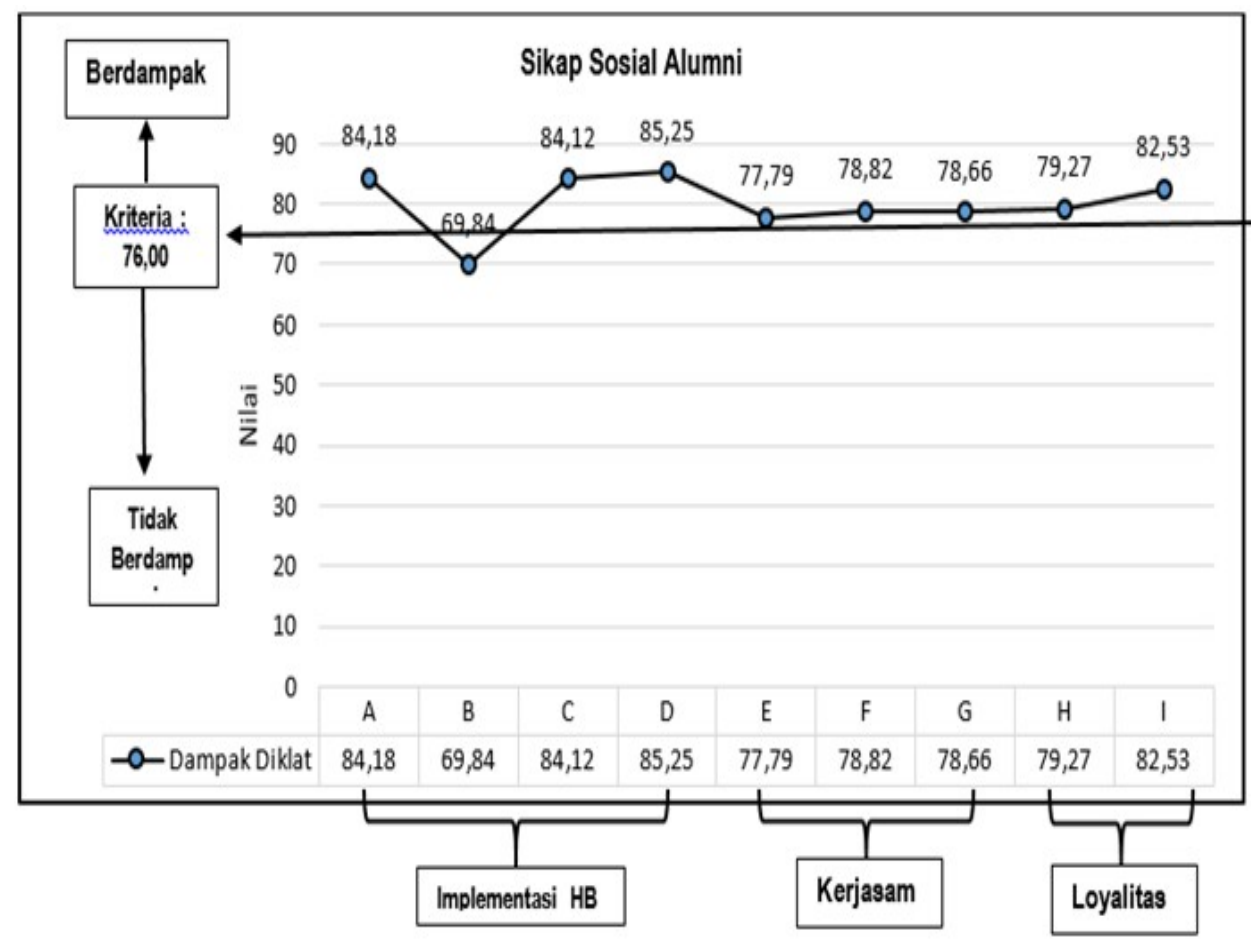

Gambar 2. Grafik Dampak Program Qiklat Terhadap Sikap Sosial Alumni

Keterangan:
$A=$ Menerapkan hasil pembelajaran yang didapat dan perubahan yang ditimbulkan

$B=$ Mengimplementasikan pengetahuan dan keterampilan yang relevan dan digunakan dalam bekerja. 
$\begin{aligned} & C= \begin{array}{l}\text { Menjaga kesinambungan } \\ \text { dari perubahan yang terjadi }\end{array} \\ & \mathrm{D}= \begin{array}{l}\text { Peningkatan kepedulian } \\ \text { terhadap tingkat perubahan }\end{array} \\ & \mathrm{E}= \begin{array}{l}\text { Bersosialisasi yang baik } \\ \text { dengan teman dan atasan }\end{array} \\ & \mathrm{F}= \begin{array}{l}\text { Melakukan kerjasama } \\ \text { secara bersamaan (team } \\ \text { work) }\end{array} \\ & \mathrm{G}= \begin{array}{l}\text { Menerima dan memberi } \\ \text { saran }\end{array} \\ & \mathrm{H}= \text { Meningkatkan kedisiplinan } \\ & \mathrm{I}= \text { Memiliki loyalitas dan } \\ & \text { persepsiterhadap pekerjaan }\end{aligned}$

\section{Pebahasan}

\section{a. Implementasi Hasil Diklat}

Pembahasan pada aspek implementasi hasil diklat dalam penelitian ini dalam rangka mengejawantahkan hasil belajar yang diperoleh alumni peserta diklat selama mengikuti diklat, baik aspek pengetahuan, aspek keterampilan maupun aspek sikap yang mengacu pada Permendikbud Nomor 19 tahun 2007 Tentang Standar pengelolaan pendidikan oleh satuan pen-didikan dasar dan menengah.

Implementasi hasil diklat diukur dengan menggunakan empat indicator, yaitu menerapkan hasil pembelajaran yang didapat dan perubahan yang ditimbulkan, m e $\mathrm{ng}$ i m ple me n tasikan pengetahuan dan keterampilan yang relevan dan digunakan dalam bekerja, menjaga kesinambungan dari perubahan yang terjadi, dan Peningkatan kepedulian terhadap tingkat perubahan

Dari empat indikator yang digunakan dalam mengevaluasi sikap sosial aspek implementasi hasil diklat, secara umum cukup berdampak. Guru madrasah yang pernah mengikuti diklat rata-rata sudah menerapkan hasil pembelajaran yang didapat ketika mengikuti diklat dan telah mengalami dan menerapkan perubahan akibat yang ditimbulkan setelah mengikuti diklat secara baik dengan nilai rata-rata 84,18 (baik).

Penerapan hasil pembelajaran oleh alumni peserta diklat tersebut mengakibatkan kebermanfaatan diklat dalam meningkatkan dan memperkuat kompetensi dan keterampilan guru. Selain itu, alumni peserta diklat mengakui dan merasakan adanya kepuasan terhadap pelayanan yang diberikan oleh penyelenggara diklat selama berlangsungnya kediklatan. Dengan optimalnya penerapan hasil pembelajaran selama diklat dalam berbagai kegiatan di Madrasah, maka dirasakan timbulnya berbagai perubahan yang lebih baik.

Akibat lain yang dapat diukur dalam implementasi hasil diklat adalah adanya penguatan keilmuan sesuai dengan spesialisasi atau mata pelajaran yang diampu dan keilmuan pengembangan diri serta 
penguatan aspek keterampilan dalam proses pembelajaran. Hal ini karena materi pelatihan yang diajarkan selama diklat hampir semuanya dapat serap dan dapat diterapkan sesuai dengan kebutuhan alumni di tempat kerja (madrasah).

Unsur kelengkapan perangkat pembelajaran bagi alumni peserta diklat juga terpenuhi dan sesuai dengan regulasi yang berlaku. Guru selaku alumni peserta diklat juga sudah banyak melakukan inovasi pembelajaran dengan pendekatan tertentu dan melakukan penilaian, baik penilaian proses yang dilakukan selama pembelajaran maupun penilaian hasil belajar.

Dampak di atas, bila dikaitkan dengan hasil wawancara terhadap 60 alumni peserta diklat ditemukan sebanyak $60,47 \%$ alumni peserta diklat mengatakan bahwa kemampuan menerapkan hasil pembelajaran dan perubahan yang ditimbulkan diperoleh dari mengikuti diklat di pusdiklat tenaga teknis pendidikan dan keagamaan. Sedangkan sisanya diperoleh dari pengembangan diri.

Hasil evaluasi sikap sosial dalam mengimplementasikan pengetahuan dan keterampilan yang relevan dan digunakan dalam bekerja secara umum masih kurang optimal $(69,84)$. Hal ini disebabkan guru selaku alumni peserta diklat masih sering mengalami kendala dan belum maksimal ketika menerapkan hasil diklat di tempat tugas (madrasah), khususnya dalam kegiatan belajar mengajar di kelas.

Hal di atas disebabkan oleh berbagai fakor, antara lain suasana kerja yang tidak kondusif terutama sikap siswa dalam memaknai arti proses pemebelajaran sebagai trsnformasi keilmuan, belum maksimalnya dukungan unsur pimpinan dan masih kuatnya pengaruh gaya pembelajaran di kelas secara konvensional yang selama ini selalu diterapkan. Namun dalam penerapan atau mendiseminasikan hasil diklat di madrasah, keterampilan yang diperoleh alumni selama diklat dan proses mengaplikasikan hasil diklat dalam melaksanakan tugas sebagai tenaga pendidik sehari-hari sudah cukup optimal.

Sikap sosial dalam mengimplementasikan hasil diklat yang lain adalah banyak guru Madrasah Tsanawiyah yang telah menjaga kesinambungan dari perubahan yang terjadi dengan baik $(84,12)$. Menjaga kesinambungan dari perubahan dilakukan oleh alumni peserta diklat dengan cara lebih meningkatkan kepedulian terhadap tingkat perubahan yang timbul di lingkungan madrasah, baik perubahan regulasi, kurikulum, dan sarana pendukung system pendidikan dan pembelajaran, menjaga kesinambungan penggunaan ilmu yang diperoleh selama diklat, tingkat 
perubahan yang terjadi dalam diri yang terus memberikan dampak positif terhadap madrasah, dan merasakan diklat memberikan pengetahuan dan skill baru dan kekinian.

Sikap sosial dalam dalam mengimplementasikan hasil diklat aspek peningkatan kepedulian terhadap tingkat perubahan telah dilakukan oleh guru dengan baik $(85,25)$, sehingga guru yang pernah mengikuti diklat merasakan adanya perubahan yang positif pada dirinya, terutama perubahan energi yang menggerakan kekutan dalam rangka mengoptimalkan kinerja dan akibat dari perubahan tersebut guru madrasah selaku alumni peserta diklat mampu dan selalu mengikuti semua kegiatan yang dipogramkan dan dilaksanakan oleh madrasah.

Kondisi di atas didukung oleh hasil wawancara dengan alumni peserta diklat yang mengatakan bahwa guru yang sudah mengikuti diklat telah melakukan perubahan dalam Sikap dan prilaku ketika melaksanakan tugas dan fungsinya, sehingga kegiatan Belajar Mengajar (KBM) dapat dilaksanakan sesuai dengn perencanaan dan lebih disiplin dalam kehadiran, lebih rajin dalam penyusunan program kerja (program tahunan, program semester) dan perangkat pembelajaran (Silabus, Rencana pelaksanaan pembelajaran, perangkat penilaian), lebih percaya diri saat mengajar dan tampil di depan kelas dan melakukan penilaian dengan system kumputerisasi.

Guru madrasah selaku alumni peserta diklat juga mengungkapkan bahwa pengetahuan dan keterampilan mereka semakin bertambah dan sudah disosialisasikan atau dikembangkan kepada teman sejawat melalui forum-forum diskusi, rapatrapat, workshop dan program MGMP. Guru madrasah juga menciptakan dan membudayakan untuk saling menghargai dan rasa empati di kalangan mereka serta kepedulian yang tinggi berkaitan dengan perilaku dan kendala cara belajar siswa.

Pernyataan di atas sesuai dengan Permendikbud Nomor 19 tahun 2007 tentang standar pengelolaan yang mengatakan bahwa setiap guru bertanggungjawab terhadap mutu kegiatan pembelajaran yang merujuk pada perkembangan metode pembelajaran yang mutakhir dan bervariasi.

Guru madrasah juga sudah berinovasi dalam menggunakan alat bantu pembelajaran, sangat memperhatikan kemampuan peserta didik, memperkaya kegiatan hasil-hasil penelitian berupa penelitian tindakan kelas dan penerapannya sehingga menghasilkan lulusan madrasah yang mudah beradaptasi, memiliki motivasi, kreatif, mandiri, dan 
mempunyai etos kerja yang tinggi.

Substansi dalam lampiran peraturan diatas lebih menekankan pada prinsip perubahan. Baik perubahan pada pola pikir guru, paradigma pembelajaran kekinian dan penerapan dalam lembaga pendidikan.

Berdasarkan hasil wawancara tertutup terhadap 60 alumni, diperoleh data dan dinyatakan bahwa peran pusdiklat dalam meningkatkan sikap sosial implementasi hasil diklat masih sangat kurang. Hal ini disebabkan banyaknya media dan sumber yang mampu membentuk guru madrasah untuk berkembang dan menggali potensi yang ada.

\section{b. Sikap sosial kerjasama}

Evaluasi sikap sosial kerjasama dalam penelitian ini mengacu pada keputusan Kepala Badan Litbang dan Diklat Kementerian Agama RI No BD/66/2013 tentang kurikulum diklat teknis fungsional peningkatan kompetensi guru madrasah dan diukur dengan tiga ranah sikap Sosial, yaitu: bersosialisasi dengan teman dan atasan, mau dan mampu bekerja secara bersamaan (team work), dan mau menerima dan memberi saran.

Sikap sosial kerjasama aspek bersosialisasi yang baik dengan teman dan atasan yang dilakukan oleh guru madrasah sudah cukup dimiliki $(77,79)$, sehingga guru yang pernah mengikuti diklat menjadi lebih baik dalam berkomunikasi dengan semua guru sebagai teman kerjanya, menjadi lebih baik dalam bergaul dengan kepala Madrash dan wakil kepala madrasah sebagai atasannya, menjadi lebih baik dalam bekerja sama dengan semua pihak, menjadi lebih aktif untuk bekerja sama dalam kelompok (KKG, MGMP atau organisasi profesi keguruan lainnya), dan lebih terbuka untuk menyampaiakn dan menerima saran yang bersifat konstruktif dalam pengembangan pembelajaran atau kelembagaan.

Alumni peserta diklat dalam berkomunikasi dengan teman kerja sesama tenaga pendidik terungkap lebih dinamis dan saling memahami sehingga sumbatan infomasi ini dapat dihindari. Alumni peserta diklatjuga mampu menciptakan kondisi menjadi lebih baik dalam bergaul dan berkomunikasi dengan kepala madrasah dan dengan wakil-wakil kepala madrasah, sehingga secara keseluruhan alumni peserta diklat menjadi lebih baik dalam bekerja sama, menjadi lebih aktif untuk bekerja sama dalam kelompok, lebih terbuka untuk menerima dan memberikan saran.

Sikap sosial kerjasama aspek kerja secara bersamaan (team work) sudah dilakukan oleh guru sudah cukup dimiliki $(78,82)$, sehingga guru aktif dalam memberikan saran, lebih kooperatif dalam mengerjakan tugas, lebih moderat 
dan tidak memaksakan kehendak, dan mau berbagi ilmu kepada sesama.

Evaluasi sikap sosial kerjasama aspek menerima dan memberi saran yang dilakukan oleh guru secara umum menunjukan cukup $(78,66)$. Sehingga guru telah menjadikan diskusi sebagai kegiatan yang menyenangkan, menjadikan pekerjaan yang dilakukan lebih kreatif dan inovatif, menyikapi perbedaan pendapat dengan megedepankan sikap toleran, menerima kekurangan dan kelebihan teman kerja, lebih memahami perbedaan karakter diantara teman kerja, dan dapat mengakomodasi sumbang saran dari teman.

Kondisi ini didukung oleh hasil wawancara yang mengatakan bahwa adanya perbaikan yang berkaitan dengan tugas dan tanggung jawab serta tingkat kehadiran di madrasah dan di dalam kelas ketika KBM, terjalinnya kerjasama dan hubungan baik dengan sesama guru, tata usaha dalam pengad-ministrasian dan kepala madrasah (perencanaan dan pelaksanaan program madrasah melalui raker atau kegiatan rutin).

Guru menghargai pendapat orang lain dan menerima dan menghargai keputusan pimpinan, senang menerima dan memberi saran dari atasan dan teman sejawat terutama dalam pembelajaran dan pembinaan siswa, lebih peduli dalam memberikan masukan kepada teman sejawat khususnya wadah MGMP, dan tingkat sosialisasi di kalangan guru sangat tinggi.

Berdasarkan hasil wawancara tertutup terhadap 60 alumni, diproleh data dan dinyatakan bahwa peran pusdiklat dalam meningkatkan sikap sosial kerjasama masih sangat kurang.

\section{c. Sikap loyalitas}

Sikap loyalitas seorang guru selaku tenaga pendidik terhadap unit kerja, tugas pokok dan fungsi sebagai tenaga pendidik atau atasan (kepala madrasah dan wakil kepala madrasah) merupakan salah satu sikap sosial yang harus ditumbuh kembangkan dalam rangka menciptakan sistem kerja yang kondusif, harmonis, profesional dan penuh tanggung jawab.

Dampak diklat unsur sikap sosial alumni peserta diklat dalam aspek sikap loyalitas baik terhadap unit kerja/madrasah maupun terhadap atasan (Kepala Madrasah dan Wakil kepala Madrasah) dapat dilihat pada dua indikator, yaitu: meningkatnya kedisiplinan dan memiliki loyalitas yang tinggi terhadap pekerjaan.

Evaluasi sikap loyalitas dalam meningkatkan kedisiplinan guru yang telah mempengaruhi sistem kerja yang berorientasi pada hasil dan kualitas sudah cukup optimal 
dengan nilai 79,27 (cukup). Guru madrasah selaku alumni peserta diklat telah melaksanakan dan meningkatkan frekuensi kehadiran di madsarah dan di ruang kelas, tingkat ketuntasan pekerjaan dan tingkat kedisiplinan menuntaskan pekerjaan cukup tinggi, datang ke madrasah maupun ke ruang kelas selalu dan dapat menyelesaikan tugasnya dengan tepat waktu.

Evaluasi sikap loyalitas dan persepsi terhadap pekerjaan sebagai guru madrasah bagi alumni peserta diklat menunjukkan cukup optimal $(82,53)$, sehingga: perhatian terhadap pekerjaannya, memahami hak dan kewajiban, peningkatan motivasi kerja, memahami tugas dan kewajiban.

Kondisi di atas didukung oleh pendapat 40 orang atasan alumni dan 60 orang teman sejawat yang secara umum mengatakan bahwa guru memiliki kedewasaan dalam menerima dan melaksanakan tugas rutin, aktif dalam peningkatan kinerja. Guru selaku alumni diklat juga memiliki peranan yang mengarah pada peningkataan kualitas input dan output peserta didik.

Guru memiliki tingkat disiplin yang tinggi, terutama masuk kerja, mengajar dan pembinaan ter-hadap siswa. Namun masih ada guru yang cenderung rendah tingkat kedisiplinan dalam mengikuti kegiatan upacara bendera mingguan yang dilaksanakan setiap hari senen.
Dampak diklat terhadap aspek loyalitas terhadap lembaga secara umum tidak stabil. Hal ini ditandai dengan ketika baru selesai diklat loyalitas meningkat namun lama kelamaan loyalitasnya menurun dan pada saat tertentu meningkat lagi.

Persepsi terhadap pekerjaan sudah menunjukkan ada peningkatan dan cara pembelajaran sudah menggunakan media pembelajaran namun belum maksimal.

Berdasarkan temuan dan pembahasan hasil wawancara tertutup terhadap 60 alumni, diproleh data dan dinyatakan bahwa peran pusdiklat tenaga teknis pendidiakn dan keagamaan melalaui diklat fungsional guru madrasah dalam meningkatkan sikap sosial loyalitas dan persepsi terhadap pekerjaan guru madrasah masih sangat kurang.

\section{PENUTUP}

\section{Simpulan}

a. Evaluasi sikap sosial alumni peserta diklat dapat menjawab permasalahan bagaimana dampak diklat terhadap sikap sosial alumni peserta diklat. Batasan evaluasi dampak program diklat terhadap sikap sosial alumni peserta diklat ini adalah implementasi hasil diklat, kerja sama, dan perilaku dan loyalitas.

b. Hasil evaluasi implementasi hasil diklat menunjukkan bahwa 
alumni peseta diklat secara umum sudah menerapkan hasil pembelajaran yang didapat selama mengikuti proses kediklatan dan perubahan yang ditimbulkan, sudah melakukan implementasi pengetahuan dan keterampilan yang relevan dengan tugas guru sebagaitenaga pendidik dan digunakan dalam bekerja, menjaga kesinambungan dari perubahan yang terjadi, dan sudah meningkatkan kepedulian terhadap tingkat perubahan dengan baik.

c. Hasil evaluasi bentuk kerjasama menunjukkan bahwa alumni peserta diklat sudah melakukan sosialisasi dengan teman dan atasan, melakukan kerja secara bersamaan (team work), dan menerima dan memberi saran dengan baik.

d. Hasil evaluasi bentuk loyalitas menunjukkan bahwa alumni peserta diklat sudah meningkatkan kedisiplinan, memiliki loyalitas dan persepsi terhadap pekerjaan dengan baik.

e. Peran pusdiklat teknis dalam peningkatan sikap sosial alumni peserta diklat baik aspek kemampuan mengimplemen-tasikan hasil diklat, kerjasama dan sikap loyalitas masih sangat rendah

\section{Rekomendasi}

a. Bagi Kepala Pusdiklat Tenaga Teknis Pendidikan dan Keagamaan: (1) Merekrut tenaga fungsional widyaiswara dan nara sumber yang memenuhi kualifikasi dan kompetensi yang sesuai dengan kebutuhan, (2) Meningkatkan daya dukung anggaran kediklatan yang memadai, (3) Melakuan Analisis Kebutuhan Diklat dalam rangka mengambil data, menganalisis dan merekomendasikan temuan untuk diklat guru madrasah, khususnya peningkatan sikap sosial guru (4) merencanakan dan menyusun kurikulum diklat dan bahan ajar pelatihan guru madrasah dengan mengakomodir dan mempetimbangkan usulan atau rekomendasi hasil analisis kebutuhan diklat, faktor kekinian dan berbasis aktivitas/ praktik.

b. Bagi praktisi:

Bagi praktisi diharapkan: (1) mendalami konsep keilmuan evaluasi program diklat, (2) mendalami konsep keilmuan dampak program diklat aspek sikap sosial dan (3) melakukan penelitian lanjutan tentang evaluasi dampak program diklat yang lebih luas. 


\section{DAFTAR PUSTAKA}

\section{Buku:}

Arikunto, Suharsimi dan Cepi Safruddin Abdul Jabar. 2014. Evaluasi Program Pendidikan: Pedoman Teoritis Bagi Mahasiswa dan Praktisi Pendidikan. Jakarta: Bumi Aksara.

Bonnie Campbell Hill dan Cyinthia Ruptic. 1994. Pactical Aspects of Authentic Assessment. Michigan: Christophr-Gordon Pubishers, Inc.

Djaali dan Puji Mulyono. 2008. Pengukuran Dalam Bidang Pendidikan. Jakarta: PT Grasindo.

Gertler, Paul. J, et. al. 2010. Impact Evaluation in Practice. Washington: World Bank.

Gronlund, Norman E dan Robert L. Linn. 1990. Measurement and Evaluation in Teaching. New York: Mac Milan Publishing Company.

Hamalik, Oemar, Evaluasi Kurikulum. 1990. Bandung: Rosdakarya.

Khandker, S.R., Koolwal, G.B., Samad, H.A. 2010. Handbook on impact evaluation. Washington, DC: The International Bank for Reconstruction and Development.

Kirkpatrikck, L Donal and james D. Kirkpatrick. 2005. Evaluating Training Programs: The Four levels, Third Edition. San Francisco: Berrett-Koehler Publishers Inc.

Raymond A. Noe, Jhon R Hollenbeck, Barry Gerhart dan Patrick Wright. 2010. Manajemen Sumber Daya Manusia, terjemahan. Jakarta: Salemba Empat,.

Robert E, Stake. 2004. Standards-Based \& Responsive Evaluation. California: Sage Publications.

Roberts, Albert R and Gilbert J. Greene. 2009. Buku Pintar Pekerja Sosial, terjemahan Juda Damanik dan Cynthia Pattiasina. Jakarta: PT BPK Gunung Mulia,

Stufflebeam, Daniel L. 2003. Internasional Handbook of Education. Boston: Published by Kluwer Academic Publishers.

Stufflebeam, Daniel L dan Anthony J. Shinkfield, 2007.Evaluation: Theory, Models, \& Applications. San Francisco: Jossey-Bass.

Yin, Robert K. 1989. Case Study Research Design and Methods. Landon: Sage Publications. 


\section{Jurnal}

Afshan Sultan, et. al. Impact Of Training On Employee Performance: A Study Of Telecommunication Sector In Pakistan. Interdisciplinary Journal Of Contemporary Research In Business Copy Right (C) 2012, October 2012 Vol 4, No 6 (diakses 3 Februari 201)

Abdus Sattar Niazi. Training Development Strategy and Its Role in Organizational Performance. Journal of Public Administration and Governance ISSN 2161-7104, 2011. Vol 1 No. 2. (diakses 19 Januari 2017

Mallonee, Sue. Evaluating Injury Prevention Programs: The Oklahoma City Smoke Alarm Project. The Future of Children Unintentional injuries in Childhood Vol 10 No 1 - Sring/summer 2000.

Yuksel, Ismail. How to Conduct a Qualitative Program Evaluation in the Light of Eisner's Educational Connoisseurship and Criticism Model. Turkish Online Journal of Qualitative Inquiry, October 2012

\section{Peraturan Perundang-undangan}

Undang-Undang Republik Indonesia Nomor 5 Tahun 2014 Tentang Aparatur Sipil Negara.

Peraturan Pemerintah Republik Indonesia Nomor 101 tahun 2000 tentang Pendidikan dan Pelatihan Jabatan Pegawai Negeri Sipil.

Peraturan Menteri Pendidikan dan Kebudayaan Nomor 19 tahun 2007 Tentang Standar pengelolaan pendidikan oleh satuan pen-didikan dasar dan menenga

Peraturan Menteri Pendidikan Nasionla Nomor 16 tahun 2007 tentang Standar Kualifikasi Akademik dan Kompetensi Guru.

Peraturan Menteri Agama Nomor 4 tahun 2012 tentang Panduan pelaksanaan kediklatan di lingkungan Kementerian Agama.

Keputusan Kepala Badan Litbang dan Diklat Kemengerian Agama RI No $\mathrm{BD} / 66 / 2013$ tentang kurikulum diklat teknis fungsional peningkatan kompetensi guru madrasah

Badan Litbang dan Diklat, 2013. Panduan Evaluasi Diklat Teknis di Lingkungan Kementerian Agama. Jakarta: Badan Litbang dan Diklat. 